http:/dx.doi.org/10.18778/7969-447-1.02

Zofia Rzeźnicka

\title{
Czy Romajos grillowat? KilKa seóW O METOdACH PRZYRZĄDZANIA PODROBÓW I MIĘSA PRZEZ LUDZI ANTYKU I BIZANCJUM
}

Pytanie zawarte w tytule artykułu na pierwszy rzut oka może wydać się co najmniej dziwne, ponieważ nasuwa skojarzenie z człowiekiem żyjącym w pierwszych wiekach naszej ery, który przygotowuje swój posiłek na urządzeniu, jakie nie dość, że zyskało szerszą popularność w drugiej połowie XX stulecia, to na dodatek zostało rozpropagowane przez Amerykanów. Jeśli jednak uważniej przyjrzymy się historii przyrządzania pokarmów, bez trudu dostrzeżemy analogie między dzisiejszymi metodami obróbki termicznej a tymi stosowanymi w starożytności i średniowieczu. Oczywiście sprzęty, którymi posługujemy się współcześnie, odbiegają wyglądem od tych używanych przez dawnych mieszkańców basenu Morza Śródziemnego, ale zarówno zasada działania, jak i rodzaj opału wykorzystywanego w dobrze znanym nam grillu węglowym nie uległy zmianie od tysięcy lat. Urządzenie to było bowiem doskonale znane zarówno w starożytnej Grecji, w Imperium Romanum, jak w czasach Bizancjum. Analiza źródeł związanych ze sztuką kulinarną dowodzi bowiem, że menu mieszkańców obszarów śródziemnomorskich, czy to w starożytności, czy też w czasach Bizancjum, nie uległo większym modyfikacjom. Oznacza to, że także sam proces przygotowywania pokarmów, mimo upływu kolejnych stuleci, czy to na wschodzie, czy zachodzie Europy, nie zmienił się zbyt drastycznie ${ }^{1}$. Dlatego też w niniejszym tekście będę odwoływać się do źródeł pochodzących z każdego z tych trzech obszarów cywilizacyjnych.

Artykuł zasadniczo opiera się na przepisach mówiących o przyrządzaniu zwierzęcych podrobów i mięsa, pochodzących z łacińskiej kompilacji przepisów kulinarnych, znanej pod tytułem De re coquinaria libri decem (O sztuce kulinarnej ksiąg dziesięć). Nie mniej istotne uzupełnienie wykładu stanowią fragmenty greckich i bizantyńskich traktatów medycznych Galena (II/III w.) i Orybazjusza (IV w.) poświęcone dietetycznej charakterystyce produktów wykorzystywanych

\footnotetext{
${ }^{1}$ Por. M.W. Adamson, Food in medieval Times, Westport, Connecticut 2004, s. 55-81; J.P. Alcock, Food in the ancient world, Westport, Connecticut-London 2006, s. 104-133.
} 
w poszczególnych recepturach. Dzieła te bowiem nie tylko ukazują opinie lekarzy na temat wpływu poszczególnych pokarmów na organizm człowieka, ale są także dowodem na brak rewolucyjnych przemian w diecie ludności zamieszkującej tereny nad Morzem Śródziemnym w początkowych wiekach naszej ery (od II do IV w.).

Rozważając zagadnienie grillowania, na początek warto przyjrzeć się bliżej rodzajom opału wykorzystywanego w interesującej nas epoce. W antyku i wczesnym Bizancjum do tego celu używano drewna i węgla drzewnego. Każde z nich było źródłem innego rodzaju płomienia i nadawało się do przygotowania innego typu potraw ${ }^{2}$. Na przykład dla szybkiego zagotowania dużej ilości wody niezbędny był intensywny ogień pochodzący z podpalonego drewna. Z kolei, aby utrzymać temperaturę podgrzanego $\mathrm{w}$ ten sposób płynu, należało ustawić garnek nad żarzącym się węglem drzewnym ${ }^{3}$. Ten drugi był zresztą chętniej używany, ponieważ po podpaleniu wytwarzał mniej dymu niż ogień pochodzący $z$ drewna ${ }^{4}$.

Przejdźmy teraz do rekonstrukcji kolejnych czynności związanych z ówczesnym grillowaniem. Najpierw w otwartym palenisku umieszczano węgiel drzewny, który następnie podpalano. Na nim ustawiano metalowy ruszt osadzony na krótkich nóżkach - nazywany po grecku éoxápa (eschara), po łacinie craticula - który, w interesującym nas okresie, był standardowym elementem wyposażenia domostw $^{5}$. Na tak przygotowanym urządzeniu kładziono mające się upiec produkty, takie jak mięso, ryby lub chleb, albo naczynie, w którym znajdowała się przygotowana do zagrzania potrawa ${ }^{6}$. Przyrządzanie dań przy użyciu rusztu nie było zatem trudne i skomplikowane - a to tylko jeden $\mathrm{z}$ kilku aspektów mających wpływ na jego popularność. Przede wszystkim była to najtańsza metoda obróbki termicznej, gdyż nie wymagała kosztownego urządzenia takiego jak piec, dodatkowe naczynia również nie były niezbędne (chociaż mogły być używane), gdyż jedzenie można było położyć bezpośrednio na eschara. Należy także pamiętać,

\footnotetext{
${ }^{2}$ Ch. Grocock, S. Grainger, Introduction, [w:] Apicius. A critical edition with an introduction and an English translation of the Latin recipe text Apicius, eds. Ch. Grocock, S. Grainger, Blackawton, Totnes 2006, s. 77.

${ }^{3}$ O pozyskiwaniu węgla drzewnego, por. S.D. Olson, Firewood and charcoal in classical Athens, „Hesperia. Journal of the American School of Classical Studies at Athens” 60 (1991), s. 412-214. O węglu drzewnym por. także M. Porci Catonis de agri cultura, XXXVIII, 4, rec. H. KeIL, Lipsiae 1895. ${ }^{4}$ J.P. ALCOCK, op. cit., s. 104.

${ }^{5}$ M. Grant, Commentary, [w:] Anthimus, On the observance of foods. De observatione ciborum, ed., transl. M. Grant, Totnes, Blackawton 2007, s. 94. O grillach w antyku, por. J.P. Alcock, op. cit., s. 108; B. Tsakirgis, Fire and smoke: hearts, braziers and chimneys in the Greek house, „British School at Athens Studies", t. 15: Building Communities: House, Settlement, and Society in the Aegean and Beyond (2007), s. 227. Grill i grillowanie w średniowiecznej Europie oraz Bizancjum, por. M.W. Adamson, op. cit., s. 60; A. Dalby, Tastes of Byzantium. The cuisine of a legendary empire, London-New York 2010, s. 173-174.

${ }^{6} \mathrm{M}$. Кокоszко, Ryby i ich znaczenie w życiu codziennym ludzi późnego antyku i wczesnego Bizancjum (III-VII w.), Łódź, 2005, s. 372-373.
} 
że nie w każdym domu wydzielone było osobne pomieszczenie kuchenne, wobec czego potrawy często przygotowywano na zewnątrz, a ruszt ustawiony na przenośnym palenisku doskonale sprawdzał się w warunkach plenerowych. Nawet jeśli mieszkanie wyposażone było w kuchnię, to była ona często pozbawiona komina, a to oznaczało, że wentylacja odbywała się przez otwór w dachu lub przez okno ${ }^{7}$. W takiej sytuacji korzystniej było podpiekać potrawy wykorzystując do tego węgiel drzewny, który nie zadymiał pomieszczenia tak bardzo, jak płomień pochodzący z palącego się drewna.

Jak już wspomniałam, na eschara pieczono między innymi mięso, które przez całą starożytność i epokę Bizancjum, z racji wysokiej ceny, stanowiło marginalny element diety ludności. Jednak przepisy mówiące o grillowaniu zawarte w De re coquinaria najczęściej dotyczą tego właśnie produktu, bądź też podrobów, toteż w swojej pracy skupię się wyłącznie na opisie tych właśnie surowców.

W antyku oraz czasach Bizancjum, tak jak dzisiaj, najpopularniejszym gatunkiem mięsa była wieprzowina. Na wysoki stopień jej spożycia miało wpływ kilka czynników. Po pierwsze, świnie hodowane były wyłącznie z przeznaczeniem na ubój, gdyż, z wyjątkiem mięsa, nie dostarczały człowiekowi innych produktów, jak mleko czy wełna. Nie były także wykorzystywane jako siła robocza. Nadto nie wymagały zapewnienia specjalnego rodzaju paszy, gdyż żywiły się roślinami, odpadkami powstałymi w wyniku produkcji wina czy oliwy ${ }^{8}$, bądź mięsem (zarówno innych zwierząt, jak i przedstawicieli swojego gatunku $)^{9} \mathrm{i}$ wszelkimi innymi resztkami. Poza tym, te wyjątkowo płodne ssaki w krótkim czasie są w stanie wydać na świat dużą liczbę prosiąt, które, w porównaniu z młodymi innych gatunków przydomowego inwentarza, dostarczają duże ilości mięsa. Prawdopodobnie więc większość receptur, mówiących o pieczeniu na ruszcie mięsa bądź podrobów bez sprecyzowania gatunku zwierzęcia, odnosi się właśnie do wieprzowiny ${ }^{10}$.

Zgodnie $\mathrm{z}$ antyczną sztuką kulinarną przed przystąpieniem do grillowania, tak jak i dzisiaj, mięso marynowano. Niemal zawsze przy sporządzaniu tego typu zalewy wykorzystywano sos rybny, nazywany po grecku yápos (garos), po łacinie garum lub liquamen. Dodatek ten charakteryzował się słonym smakiem i znany był już w V w. p.n.e. ${ }^{11}$. Stosowano go do przyprawiania mięs ${ }^{12}$, warzyw (na przykład

\footnotetext{
${ }^{7}$ P. FaAs, Around the Roman table. Food and feasting in ancient Rome, transl. S. Whiteside, Chicago 2005, s. 130.

${ }^{8}$ F. Frost, Sausage and meat preservation in antiquity, „Greek, Roman, and Byzantine Studies" 40 (1999), s. 243; M.L. Rautman, Daily life in Byzantine Empire, Westport, Connecticut 2006, s. 184185.

9 F. Frost, op. cit., s. 243; A. Dalby, Food in the ancient world from A to Z, London-New York 2003, s. 269.

${ }^{10}$ Wyjątek może stanowić przepis na wątróbkę ficatum, która mogła pochodzić od tuczonych świń lub gęsi. Por. poniżej.

${ }^{11}$ A. Dalby, op. cit., s. 156.

${ }_{12}$ Por. poniżej.
} 
ogórkó $w^{13}$, kapusty $^{14}$, porów ${ }^{15}$, karczochów ${ }^{16}$ ), owoców (na przykład cedratów ${ }^{17}$ czy melonów ${ }^{18}$ ) i ryb ${ }^{19}$. Produkt ten powstawał w wyniku zasolenia ryb, całych lub ich wnętrzności ${ }^{20}$. Najczęściej do tego celu wykorzystywano niewielkie okazy sardynek, szprot, barwen i sardeli ${ }^{21}$. Jedną z bardziej znanych odmian tego delikatesu było wytwarzane w Hiszpanii garum sociorum ${ }^{22}$, które charakteryzowało się złotawą, przezroczystą barwą i intensywnym zapachem ${ }^{23}$. Na podstawie informacji zawartych w Geoponica, bizantyńskiej encyklopedii rolniczej datowanej na X w., można zrekonstruować sposoby przygotowania sosu rybnego. Jedna z metod polegała na zasoleniu znajdujących się w naczyniu rybich wnętrzności, na których umieszczano całe ryby, które również pokrywano warstwą konserwantu. Zawartość garnka poddawano procesowi fermentacji, wystawiając go na słońce. Aby wszystkie składniki dokładnie połączyły się ze sobą, naczyniem często energicznie potrząsano. Produkt uznawano za gotowy, gdy zawartość pojemnika przestała się burzyć. Na sam koniec płyn odcedzano od rybnych pozostałości $i^{24}$. Warto też wspomnieć, że z powodu swoich właściwości smakowych garum zastępowało sól. $\mathrm{Na}$ bazie tego produktu przygotowywano inne sosy, jak sos rybny na winie, określany po grecku oivóyapov (ojnogaron), po łacinie oenogarum lub garum, z dodatkiem octu, tak zwane ỏ úkpatov (oksykraton), łacińskie oxygarum.

Liquamen w De re coquinaria, wymienione zostało na przykład w przepisie na wątróbkę, którą autor receptury określił przymiotnikiem ficatum. Słowo to oznacza, że organ ten pozyskano od zwierzęcia (świni lub gęsi) tuczonego suszonymi figami. Zabieg ten, którego celem było zniwelowanie naturalnej goryczy wątroby, z powodzeniem praktykowany był już w starożytnej Grecji i przetrwał do epoki Bizancjum. Mieszkańcy wschodnich obszarów położonych nad Mo-

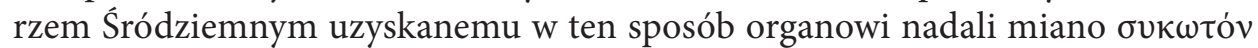
(sykoton). Wzmianki na temat rzeczonego produktu zamieszczone w źródłach

\footnotetext{
${ }_{13}$ Apicjusz, O sztuce kulinarnej ksiąg dziesięć, III, 6, 1-3, tekst, tłum., kom. I. MikoŁajczyк, S. Wyszomirski, Toruń 1998 (dalej: ApICjusz, De re coquinaria).

${ }^{14}$ Apicjusz, De re coquinaria, III, 9, 1; III, 9, 3.

${ }_{15}$ ApICjusz, De re coquinaria, III, 10, 1.

16 ApIcjusz, De re coquinaria, III, 19, 1-3.

17 Apicjusz, De re coquinaria, III, 5.

18 ApIcjusz, De re coquinaria, III, 7.

${ }_{19}$ Na przykład: ApICjusz, De re coquinaria, IV, 2, 20; X, 1, 1-3; X, 2, 1-18; X, 3, 1-2. Por. R.I. CuRTIS, Product identification and advertising on Roman commertial amphore, „Ancient Society” 15-17 (1984-1986), s. 212.

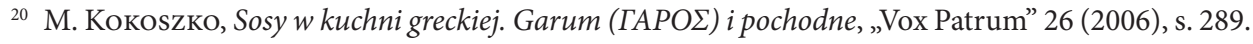

${ }^{21}$ M. Кокоszко, Sosy w kuchni greckiej..., s. 291.

${ }^{22}$ R.I. CurTis, op. cit., s. 221.

${ }^{23}$ M. Кокоszко, Sosy w kuchni greckiej..., s. 290.

${ }^{24}$ Geoponica sive Cassiani Bassi Scholastici de re rustica eclogae, XX, 46, 1-2, rec. H. BecKH, Lipsiae 1895. Por. М. Кокоszко, Sosy w kuchni greckiej..., s. 290-291. Na temat innych metod produkcji garos, por. także Geoponica, XX, 46, 3-6; M. Kокоszко, Sosy w kuchni greckiej..., s. 291-292.
} 
niezwiązanych z gastronomią, takich jak Historia naturalis Pliniusza Starszego oraz Geoponica, świadczą o jego niesłabnącej popularności zarówno w greckojęzycznej, jak i łacińskiej części Mare Mediterraneum. Rzymski encyklopedysta podaje na przykład, że wątrobę tuczonych gęsi należy zanurzyć w mieszaninie mleka i wina słodzonego miodem (mulsum), dzięki czemu ficatum zwiększy swój rozmiar $^{25}$. Z kolei autor Geoponica radzi umieścić sykoton w naczyniu ze świeżą i czystą wodą, która powinna być wymieniana dwa bądź trzy razy na dzień ${ }^{26}$. Powyższe wskazówki zapewne odnoszą się do wstępnego przygotowania wątroby przed poddaniem jej obróbce termicznej. Zgodnie z recepturą zawartą w De re coquinaria, ponacinaną wątrobę najpierw należało zamarynować w mieszaninie sosu rybnego (liquamen), pieprzu, lubczyku oraz kilku jagód lauru, a następnie zawinięty w błonę otrzewnową surowiec (co chroniło go przed wysuszeniem) grillowano $^{27}$. Przygotowaną w ten sposób potrawę podawano z sosem składającym się z sosu rybnego, oliwy oraz wina z dodatkiem pieprzu, tymianku i lubczyku ogrodowego ${ }^{28}$.

Wątroba specjalnie tuczonych zwierząt była także obiektem zainteresowania greckich i bizantyńskich lekarzy. Na podstawie dzieł Galena i Orybazjusza możemy stwierdzić, że wysoka ocena jej właściwości dietetycznych nie uległa zmianie w okresie od II do IV w. Obaj medycy w swoich traktatach uwypuklili bowiem te same cechy sykoton pisząc, że jest wyjątkowo smaczne ${ }^{29}$ i pożywne ${ }^{30}$, a nadto stymuluje organizm do produkcji dobrych soków ${ }^{31}$. Zgodnie stwierdzili też, że tego typu pożywienie z łatwością przechodzi przez układ pokarmowy ${ }^{32}$.

Inna receptura dotyczy przyrządzania wymienia (prawdopodobnie świni), które również uważane było za przysmak, o czym świadczą dane zawarte w greckich i łacińskich źródłach. Pliniusz Starszy podaje, że narząd ten jest najlepszy, jeśli pochodzi od świni zabitej dzień po wydaniu na świat potomstwa, pod warunkiem, że nie karmiła ona jeszcze młodych. Z pism Galena i Orybazjusza dowiadujemy się, że pokarm ten smakosze upodobali sobie z powodu słodkiego posmaku

\footnotetext{
${ }_{25}$ Pliny, Natural history with an English translation in ten volumes, X, 27, 52, transl. H. RackHAm, t. 3, Cambridge, Mass.-London 1956 (dalej: Pliniusz, Historia naturalis). Por. J. André, L' alimentation et la cuisine à Rome, Paris 1961, s. 132; P. Faas, op. cit., s. 253.

${ }^{26}$ Geoponica, XIV, 22, 15.

27 ApICjusz, De re coquinaria, VII, 3, 2. Współczesna wersja przepisu, por. S. GraINGER, Cooking Apicius. Roman recipes for today, Blackawton, Totnes 2006, s. 47.

${ }_{28}$ APICJusz, De re coquinaria, VII, 3, 1. Współczesna wersja przepisu, por. P. FAAs, op. cit., s. 258-259.

${ }^{29}$ Galeni de alimentorum facultatibus libri III, 679, 7-8; 704, 3-4, [w:] Claudii Galeni opera omnia, ed. C.G. KüHN, t. VI, Lipsiae 1823; Oribasii collectionum medicarum reliquiae, II, 39, 2, 1-2; II, 44, 2, 1-2, ed. I. RAEDER, t. 1-4, Lipsiae-Berolini 1928-1933.

${ }^{30}$ Galen, De alimentorum facultatibus, 704, 3-6, t. 6; Orybazjusz, Collectiones medicae, II, 44, 2, 1-4.

${ }^{31}$ Galen, De alimentorum facultatibus, 704, 3-6, t. 6; Orybazjusz, Collectiones medicae, II, 44, 2, 1-4.

32 Galen, De alimentorum facultatibus, 704, 3-7, t. 6; Orybazjusz, Collectiones medicae, II, 44, 2, 1-3, 1.
} 
mleka zgromadzonego w mieszczących się w wymieniu gruczołach ${ }^{33}$. Autor przepisu zawartego w De re coquinaria radzi, aby przed położeniem na ruszt twardy $\mathrm{z}$ natury surowiec zmiękczyć obgotowując go w wodzie. Kolejno należało spiąć produkt szpikulcami, nasolić $\mathrm{i}$ upiec na ruszcie. Gotowe danie serwowano z dodatkiem gorącego, zagęszczonego skrobią sosu przygotowanego $\mathrm{z}$ utartego pieprzu, lubczyku ogrodowego, garum, wina lub passum, czyli trunku $\mathrm{z}$ winnej latorośli sporządzonego z rodzynek ${ }^{34}$.

Kolejnym produktem poddawanym grillowaniu były nerki (zapewne również wieprzowe), choć, jak wynika z treści traktatów medycznych, podroby te nie odznaczały się szczególnymi walorami dietetycznymi. Galen, tak samo jak później Orybazjusz, uznał, że charakteryzują się one zapachem uryny ${ }^{35}$ oraz zakłócają równowagę humoralną $\mathrm{w}$ organizmie człowieka ${ }^{36}$. Pomimo tego niekorzystnego opisu potrawy z nerek miały swoich amatorów, czego dowodzi chociażby przepis pochodzący z De re coquinaria. Zgodnie z zawartymi w nim wskazówkami rozcięte na pół podroby doprawiano pieprzem, orzeszkami piniowymi, drobno posiekaną kolendrą i utartymi ziarnami kopru włoskiego. Następnie obie części zszywano, owijano w błonę otrzewnową i najpierw podsmażano na oliwie z oliwek $\mathrm{z}$ dodatkiem sosu rybnego, a potem pieczono na craticula lub ewentualnie w przenośnym piekarniku ${ }^{37}$.

Na ruszcie grillowano nie tylko podroby, ale też porcjowane mięso, jak chociażby smakołyk nazywany po łacinie ofellae. W antycznym Rzymie terminem tym określano popularną potrawę przyrządzoną $\mathrm{z}$ drobno pokrojonego, marynowanego, duszonego surowca ${ }^{38}$. Autor jednego z przepisów zawartego w $D e$ re coquinaria poleca okrojone $\mathrm{z}$ kości i nadmiaru tłuszczu, zwinięte w rulonik i spięte szpikulcami mięso upiec $\mathrm{w}$ piecu. Następnie surowiec osuszano $\mathrm{z}$ nadmiaru soków, kładąc go na ruszcie, pod którym tlił się niewielki żar. W tym czasie sporządzano sos składający się z pieprzu, lubczyku ogrodowego, cibory, kminu rzymskiego, liquamen i wina z rodzynek (passum), a później mięso duszono w powstałej w ten sposób zalewie. Mięso serwowano osuszone z płynu i posypane pieprzem $^{39}$.

W kulinarnym dziełku znajdujemy również przepis mówiący o grillowaniu mięsa koźląt lub jagniąt. Zwierzęta te $\mathrm{w}$ antyku i epoce bizantyńskiej stanowiły ważną część przydomowego inwentarza. Jednak, w przeciwieństwie do świń, kozy

${ }^{33}$ Galen, De alimentorum facultatibus, 674, 10-15, t. 6; OrybazJusz, Collectiones medicae, II, 32, 2, 2-3.

${ }^{34}$ ApICjusz, De re coquinaria, VII, $2,1$.

${ }^{35}$ Galen, De alimentorum facultatibus, 675, 5-7, t. VI; OrYBazjusz, Collectiones medicae, II, 32, 4, 1-4, 4.

${ }_{36}$ Galeni de probis pravisque alimentorum succis, 771, 10, [w:] Claudii Galeni opera omnia, ed. C.G. KüHN,

t. 6, Lipsiae 1823; Orybazjusz, Collectiones medicae, II, 33, 1, 1.

${ }^{37}$ ApICjusz, De re coquinaria, VII, 8, 1.

38 A. Dalby, Food..., s. 237.

39 ApICjusz, De re coquinaria, VII, 4, 2. 
i owce hodowano przede wszystkim ze względu na mleko ${ }^{40}$, które, zwłaszcza na wsi, było jednym $\mathrm{z}$ podstawowych napojó $\mathrm{w}^{41}$, a także surowcem, $\mathrm{z}$ którego wyrabiano sery $^{42}$. Oprócz tego owce dostarczały wełnę, z której wytwarzano przędzę. Oba gatunki zwierząt odgrywały więc $\mathrm{w}$ gospodarstwie istotną rolę i dlatego stosunkowo rzadko przeznaczane były na ubój. Mając na uwadze powyższe argumenty oraz fakt, że przepis wymaga użycia delikatnego mięsa młodego koziołka lub baranka, możemy przypuszczać, że receptura skierowana była do zamożnych amatorów dobrej kuchni. Mieszkańcy terenów położonych nad Morzem Śródziemnym cenili potrawy przyrządzone z młodych sztuk, gdyż taki surowiec pozbawiony jest charakterystycznego intensywnego zapachu. Nadto mięso to jest miękkie, co oznacza, że jego obróbka termiczna nie trwa zbyt długo. W tym miejscu warto jeszcze zwrócić uwagę na kolejny czynnik warunkujący jakość koźliny i baraniny, o którym wspomnieli greccy i bizantyńscy medycy, czyli na porę roku, w której zabijano te zwierzęta. Zgodnie z doktryną utrwaloną przez Galena, którą w IV w. powtórzył Orybazjusz, mięso wspomnianych stworzeń najlepiej spożywać w okresie od późnej wiosny do wczesnego lata, kiedy to kozy i owce miały pod dostatkiem zielonej paszy, co korzystnie wpływało na jego walory smakowe ${ }^{43}$. Ci sami znawcy sztuki medycznej w swoich traktatach dokonali krótkiej charakterystyki dietetycznej obu gatunków mięs. Pisząc o jagnięcinie Galen uznał, że mieści ona w sobie wiele wilgoci i flegmatycznych humorów ${ }^{44}$. Cechy te odnotował również Orybazjusz ${ }^{45}$, który w innym fragmencie swego dzieła stwierdził też, że surowiec pochodzący z owieczek karmionych mlekiem odznacza się lekkostrawnością, jest pożywny i nawilża wnętrzności, na przykład żołądek ${ }^{46}$. Lepszą opinią cieszyło się mięso koziołków. Galen zauważył bowiem, że z powodu niedużej ilości niepodlegającej trawieniu wilgoci stanowi ono lepszy pokarm niż produkt pozyskany z młodych zwierząt innych gatunków ${ }^{47}$. Z kolei Orybazjusz opisuje koźlęta jako pożywienie lekkostrawne, pożywne i nawilżające żołądek ${ }^{48}$. Na podstawie przedstawionych

\footnotetext{
${ }^{40}$ M. Terenti Varronis rerum rusticarum, II, 1, 4, eds. W.D. Hooper, H.B. Ash, Londini 1934; Lucius Julius Moderatus Columella, On agriculture in three volumes. Res rustica V-IX, VII, 2, 1-2, ed., transl. E.S. Forster, E.H. Heffner, t. 2, London-Cambridge, Mass. 1954. Również por. A. Dalby, Food..., s. 300; J.P. Alсоск, op. cit., s. 67-68; J.M. Wilkins, S. Hill, Food in the ancient world, Malden, Mass.-Oxford 2006, s. 131; J.M.C. ToynbeE, Animals in Roman life and art, Barnsley, South Yorkshire 2013, s. 164-165.

${ }^{41}$ J.M. Wilkins, S. HiLl, op. cit., s. 161-162.

${ }^{42}$ A. Dalby, Siren feasts. A history of food and gastronomy in Greece, London-New York 1996, s. 58.

${ }^{43}$ Galen, De alimentorum facultatibus, 666, 1-3, t. VI; Orybazjusz, Collectiones medicae, II, 28, 16, 7-9.

${ }^{44}$ Galen, De alimentorum facultatibus, 663, 12, t. VI.

${ }^{45}$ Orybazjusz, Collectiones medicae, II, 28, 7, 1-2.

${ }^{46}$ Orybazjusz, Collectiones medicae, II, 68, 3, 3-4, 1.

${ }^{47}$ Galeni de temperamentis libri III, 579, 1-8, [w:] Claudii Galeni opera omnia, ed. C.G. KüHN, t. 1, Lipsiae 1821.

${ }^{48}$ Orybazjusz, Collectiones medicae, II, 68, 3, 1-4, 1.
} 
powyżej informacji możemy więc przypuszczać, że potrawa przyrządzona zgodnie z przepisem zawartym w De re coquinaria mogła w oczach medyków uchodzić za wartościowy pokarm. Zgodnie z treścią receptury koźlę lub jagnię na początku należało dusić w mieszaninie sosu rybnego i oliwy. Kolejno mięso było dzielone na kawałki i marynowane w zalewie składającej się z pieprzu, asafetydy ${ }^{49}$, liquamen i niedużej ilości oliwy. Po zdjęciu z rusztu gotowe danie polewane było powtórnie tym samym sosem ${ }^{50}$.

Zaprezentowane powyżej receptury dowodzą, że w antyku grillowanie było powszechnie praktykowaną, niedrogą formą obróbki termicznej. Technologia ta przetrwała całą starożytność i znana była również w czasach Bizancjum. Żar tlący się pod rusztem zapewniał staranne upieczenie produktu, czego nie gwarantowało przyrządzanie potraw nad żywym płomieniem, który zazwyczaj przypalał je $\mathrm{z}$ zewnątrz, pozostawiając surowe $\mathrm{w}$ środku. $\mathrm{Z}$ De re coquinaria dowiadujemy się również, że ruszt mógł być także wykorzystywany jako narzędzie w jednym z kilku etapów przyrządzania potraw, przy osuszaniu ich z nadmiaru soków. Analiza przepisów zawartych w kulinarnym opusculum dowodzi też, że do pieczenia na eschara/craticula idealnie nadawały się podroby (wątróbka, wymię, nerki) oraz nieduże porcje mięsa (wieprzowiny, jagnięciny, koźliny). Zazwyczaj surowiec był najpierw marynowany w aromatycznych zalewach przygotowanych na bazie z sosu rybnego, oliwy oraz rozmaitych przypraw. Z kolei lektura greckich i bizantyńskich traktatów medycznych dowodzi, że pokarmy przyrządzone z mięsa oraz zwierzęcych narządów wewnętrznych były stałym obiektem zainteresowania ówczesnych medyków, którzy w swoich dziełach doradzali czytelnikom, czym należy kierować się przy wyborze surowców jak najlepszej jakości.

\footnotetext{
${ }^{49}$ Gumożywica o silnym aromacie, otrzymywana z korzeni i kłączy zapaliczki cuchnącej (Ferula Assa-foetida). Ważny składnik antycznej kuchni, gdzie dostępna była w postaci sproszkowanej lub grudkowatej masy, por. M. Kокоszко, Ryby..., s. 387. Więcej na ten temat, por. A. DALby, Dangerous tastes. The story of spices, London 2002, s. 110-112.

${ }_{50}$ ApICjusz, De re coquinaria, VIII, 6, 4.
} 